\title{
The Intervening Effect of the Dividend Policy on Financial Performance and Firm Value in Large Indonesian Firms
}

\author{
Perdana Wahyu Santosa ${ }^{1}$, Ovinda Aprilia ${ }^{2} \&$ Martua Eliakim Tambunan ${ }^{3}$ \\ ${ }^{1}$ Program Master of Management, YARSI University, Indonesia \\ ${ }^{2}$ School of Business and Management, Bandung Institute of Technology, Indonesia \\ ${ }^{3}$ Program Master of Management, Christian University of Indonesia, Indonesia \\ Correspondence: Dr. Perdana Wahyu Santosa, YARSI University, Jl. Letjen Suprapto, Cempaka Putih, Jakarta, \\ Indonesia. E-mail: pwsantosa@gmail.com
}

Received: December 21, 2019

Accepted: March 18, 2020

Online Published: July 7, 2020

doi:10.5430/ijfr.v11n4p408

URL: https://doi.org/10.5430/ijfr.v11n4p408

\begin{abstract}
This study aims to examine the relationship between financial performance with firm value with dividend policy as an intervening variable in an emerging market, Indonesia. The samples in this study are large firms listed on the Indonesia Stock Exchange (IDX). The sampling method uses a purposive sampling technique according to research criteria, especially members of the LQ45 index. The study used the data analysis by using multiple regression analysis, path analysis, and Sobel test to find the direct, indirect, and intervening effect and significance in this study. The results indicated that profitability and activity have a positive effect, leverage has a negative effect, but liquidity has no effect on the value of the firms. The subsequent analysis shows that profitability and leverage do not affect dividend policy, liquidity has a negative effect, while activity has a positive effect, significantly. Dividend policy has a positive effect on firm value. Liquidity and leverage do not affect the firm value, but profitability and activity effect positively on the firm value through intervening dividend policy. Conclusions: in general, financial performance indicates an influence on firm value and less effect on dividend policy. As an intervening variable, dividend policy weakens the effect of financial performance on firm value.
\end{abstract}

Keywords: financial performance, firm value, dividend policy, large firms, IDX

\section{Introduction}

Financial performance, corporate dividend policy, and firm value have remained essential but also an ambiguous issue in corporate finance literature. Some studies in corporate finance have tried to determine the effect of inter-relationship financial performance, dividend policy on the value of the firm, but results are still conflicting (Santosa, 2020). The influence of financial performance on firm value and dividend policy directly and the impact of dividend policy on the value of a firm became a critical view. Some literature presented the reason that a firm's value is not related to its dividend policy, unlike the profitability. In a perfect financial market, most investors are not interested in cash dividends or capital gains. This view is only accurate under the condition that investors and managers get the information about the financial position, equally. Nonetheless, some investors prefer to present cash streams rather than expected future cash flows in the form of capital gain (Kasmiati and Santosa, 2019; Osamwonyi1 \& Lola-Ebuek,2016; Yegon et al., 2014; Van Horne \& Wachowics, 2012).

The capital structure of the firm is the composition of total debt (current and long term debt), owner equity, and any other sources of endowments to funds its long term assets. Aligning the capital structure and dividend policy with the company's strategy is a crucial task and needs critical analysis (Rehman, 2016) and contending that strategic decision of capital structure is crucial to many other decisions in corporate finance, especially financing decision. Most of the theories emphasize on balance between debt and equity, which is then a known optimized capital structure or the optimal target leverage (Shah and Khan, 2010, Santosa and Puspitasari, 2019). Rehman (2016) explained that the optimum capital structure that the target of the company leverage setting by balancing its marginal cost and marginal benefits. If the debt portion increased, tax shield (deductible) could be achieved, but it can boost the risk of financial distress and removing control for the investors. Therefore, pronouncement making in the capital structure engineering and dividend policy conjointly called financial leverage policy is precarious matter to all firms due to its 
direct effect on the firm value. Literature shows that firms use a practical approach in designing the capital structure and try to align it with the strategy, which is flexible and responding to the changing circumstances in the capital market (Brigham and Houston, 2016; Rehman, 2016).

Santosa et al. (2020) show that profitability has a significant positive effect on dividend policy, while company size, leverage, and free cash flow in the study do not affect dividend policy. These results support Putu et al. (2014) by using path analysis for the variable profitability of firm value with dividend policy as an intervening variable, the results concluded that profitability has a significant positive effect on dividend policy and dividend policy has a significant positive effect on firm value. Nevertheless, Sugiastuti et al. (2018) opinion showed that profitability and dividend policy does not have a significant positive effect on firm value. However, profitability has a positive and significant effect on dividend policy and dividend policy, unable to mediate the relationship between the effect of profitability and firm value, whereas Rehman (2016) and Apriadi et al. (2016) explained that profitability proxied by ROA and ROE has a significant effect on firm value; however, liquidity does not effect on firm value.

Based on the results of research conducted by some scholars said that liquidity has no effect; leverage has no effect, and profitability has no effect on firm value, and dividend policy cannot moderate the financial performance of the firm's value. However, Rehman (2016) and Lubis et al. (2017) suggested that capital structure has a positive effect; leverage has a positive effect, and profitability has a significant positive effect, and dividend policy has a positive effect on firm value. Putu et al. (2014) found that dividend policy has a positive effect, influential debt policy, and profitability has a positive and significant effect on firm value. Furthermore, Kasmiati and Santosa (2019) found that profitability had a positive influence on dividend policy; dividend policy has a positive influence on the value of the company; profitability has a positive effect on firm value, and dividend policy is proven to mediate the effect of profitability on firm value. From some of the previous studies, it creates crucial research gaps for this research.

This study purposes of examining the impact of financial performance on firm value with dividend policy as an intervening variable (mediating) of large Indonesian firm in an emerging market. The population in this study are large companies listed on the Indonesia Stock Exchange (IDX). This study examines whether the financial performance, which is proxied by liquidity, solvability, activity, and profitability, affect firm value significantly with and without mediating of intervening variables, such as dividend policy. One rationale of the study is that prior works of literature consider profitability, liquidity, capital structure, and efficiency design impact on the firm value or dividend policy influence on firm value. It looks like that both (financial performance design and dividend policy) factor impact on measuring the firm value in large Indonesian firms is not yet discussed clearly. The hypothesis, analysis models, results, and discussions, findings, and conclusions are presented in subsequent sections.

\section{Literature Review and Hypothesis}

Some theoretical kinds of literature related to financial performance and the firm value that listed on the capital market show consistent results, which are generally positively correlated between the two. In this context, financial performance influences firm value positively, theoretically (Brigham and Houston, 2016; Santosa, 2020). In this case, management must improve the company's financial performance, especially the four most essential ratios, such as liquidity, solvency, activity, and profitability, so that corporate achieves the objectives. The main goal of management is to maximize wealth shareholders by increasing share prices and company value (Brigham and Houston, 2016). Of the four essential ratios, investors consider profitability to be the most crucial factor for their equity investment decision, especially the aspect of sustainability of long-term profitability (Lubis et al. 2014). Anyone and any form of management to the extent that it can produce profitability that is growing consistently, investors will support it (Putu et al. 2014; Kasmiati and Santosa, 2019).

Profitability is the company's ability to earn profits with sales, total assets, and its capital. According to Kasmiati and Santosa (2019), profitability ratios are very beneficial for the survival of the company because it can help companies to determine the contribution of company profits in the short or long term. The company's profitability proxied by the return on Equity (ROE). Liquidity is a ratio that represents the company's ability to meet short-term obligations. High or low company liquidity can affect a company's dividend policy (Kanwal and Hameed, 2017). The liquidity ratio generally used is the current ratio by dividing current assets with current liabilities. The leverage reflects the company to fulfill all long-term liabilities shown by some part of its capital used to pay debts (Putu et al. 2014; Subrahmanyam, 2014). Leverage be proxied by the total debt to equity ratio (DER). The activity ratio is the ratio used to know the level of efficiency to create sales/revenue, directly. The total assets turnover (TATO) represents the activity ratio (Subramanyam, 2014; Sugiastuti et al., 2018).

Imelda and Sheila (2018) show that profitability has a positive effect on dividend policy, company size has no effect on dividend policy, leverage does not affect dividend policy, and free cash flow has no effect on dividend policy. 
Furthermore, Sugiastuti et al. (2018) stated that profitability proved to have a positive effect; investment decisions proved to have a positive effect; company growth was proven not to affect firm value. Other findings show that profitability has a positive effect, investment decisions have no effect, company growth has no effect on dividend policy, and dividend policy has no significant effect on firm value.

Lubis et al. (2017) and Imelda and Sheila (2018) found that the current ratio had a significant positive effect; the debt to equity ratio has a significant negative effect; total assets turnover has a significant positive effect; ROE does not affect firm value. Assets turnover and ROE have a significant effect on firm value. Research conducted by Pertiwi (2016) shows that profitability is not significantly positive effect; dividend policy is not a significant positive effect; profitability has a positive and significant effect on dividend policy, but the Dividend policy is not able to mediate the relationship between the effect of profitability with firm value. Meanwhile, based on the results of Faroog's research (2016), the results show that leverage has a significant and positive effect on firm value, and firm value effect on firm size, negatively.

\subsection{Hypothesis Development}

\subsubsection{Effect of Profitability on Firm Value}

Pertiwi (2016), Putu et al. (2018), Lubis, et al. (2017) obtained results that profitability has a positive and significant effect on firm value. This positive correlation is happening because if profitability is increasing, then the company's ability to pay dividends is also higher. Therefore, it will attract investors so that the value of the company will increase through an increase in share prices (Sugiastuti et al. 2018; Apriadi et al. (2016). Equity investors more attention to the long-term profitability and sustainability of large firms as the guarantee required of return and maximization shareholders' wealth. Based on the results of previous studies, then the hypothesis can be formulated as follows:

\section{H1: Profitability effect on firm value positively related to Indonesian's large firms (+).}

\subsubsection{Effect of Liquidity on Firm Value}

The ability of companies to cover short-term liabilities will be responded positively by the market, and this supports the concept of signaling theory. The market will boost confidence in the company when this high level of liquidity shows that these companies have excellent performance with low operating risk and low return, otherwise (Kasmiati and Santosa, 2019; Subrahmanyam, 2014). However, based on research conducted by Kanwal and Hameed (2017), Sugiastuti et al., (2018), and Pertiwi (2016) show that liquidity does not affect or negative impact on firm value. Based on the previous theory, the following previous studies, the hypothesis can be formulated:

\section{H2: Liquidity impact on firm value positively/negatively related to Indonesian's large firms (+/-).}

\subsubsection{Effect of Leverage on Firm Value}

The leverage measures the company's ability to meet its long-term obligations. Where higher leverage generally increases the probability of financial distress and bankruptcy (Van Horne and Wachowics, 2012; Kasmiati and Santosa, 2019). Based on the results of examine, Faroq (2016) explains that leverage has a positive and significant effect on firm value. However, the results of the study were not in line with the results of the study conducted by Lubis et al. (2017) and Gill (2012), who said that leverage had a significant effect on firm value, negatively. Based on the results of previous studies, then the hypothesis can be formulated as follows:

\section{H3: Leverage effect on firm value negatively related to Indonesian's large firms (-).}

\subsubsection{Effect of Activity on Firm Value}

Based on the results of the study conducted by Putu et al. (2018) stated that Total Assets Turnover has a significant positive effect on firm value. These results are in line with research conducted by Sugiastuti et al. (2018), who say that efficiency has a significant positive effect on firm value. The efficiency ratio is considered beneficial for creditors and company' owners (shareholders) because it can show the level of efficiency of the company to increase sales and TATO is also useful for company management to find out how effectively the company manages its assets to increase value company (Brigham and Houston, 2016). Based on the results of previous studies, then the hypothesis can be formulated as follows:

\section{H4: Activity effect on firm value positively related to Indonesian's large firms (+).}

\subsubsection{Effect of Profitability on Dividend Policy}

Based on the results of an analysis conducted by Adediran and Alade (2013), Sugiastuti et al. (2018), who examined the effect of profitability on dividend policy, stated that profitability had a significant positive effect on dividend policy. In short, almost researchers found a positive relationship between profitability and dividend policy and firm value. 
Besides that, profitability and dividend policy found to have a positive impact on the firm value and shareholders' wealth (Hashim and Davidas, 2018; Sandy and Asyik, 2013). Based on the results of previous studies, then the hypothesis can be formulated as follows:

H5: Profitability effect on dividend policy positively related to Indonesian's large firms (+).

2.1.6 Effect of Liquidity on Dividend Policy

The company's liquidity position affects the ability to pay dividends because dividends are paid in cash and not with retained earnings, so the company must have cash available for dividend payments (Brigham and Houston, 2016). Therefore, a company that has good liquidity is more likely to pay dividends as well. Improved liquidity reflects an increase in cash owned by the business entity (Kanwal and Hameed, 2018). If liquidity shows a bad condition, the company may not be able to pay dividends. Thus, liquidity influences the dividend payout ratio. These findings are in line with research conducted by Sandy and Ali (2016), Asyik (2013); Putu et al. (2014), Sugiastuti et al. (2018) and Hashim and Davidas (2018), which shows that liquidity positively influence or does not impact on dividend policy depend on corporate governance consideration. Based on the explanations of previous studies, we formulated the hypothesis as follows:

\section{H6: Liquidity impact on dividend policy positively related to Indonesian's large firms (+).}

\subsubsection{Effect of Leverage on Dividend Policy}

Putu et al. (2014) and Santosa et al. (2020) find that leverage harms dividend policy. They explain that the higher the composition of debt to own capital, there is a tendency for the lack of dividend policy priorities. The more debt that a firm must pay, the higher the funds that must provide so that it will reduce the number of dividends to pay to shareholders (Kajola et al. 2015; Kanwal and Hameed, 2018; Sandy and Asyik, 2013). Based on the results of previous studies, then we formulated the hypothesis as follows:

\section{H7: Leverage effect on dividend policy positively related to large Indonesian firms (+).}

\subsubsection{Effect of Activity on Dividend Policy}

Research conducted by Kajola et al. (2015) and Brigham and Houston (2016) find that the ratio of activities that are proxied to total asset turnover has a positive and significant effect on the dividend payout ratio. Also, the results of research conducted by Kolawole et al. (2018) and Van Horne and Wachowics (2012) explain that assets efficiency has a significant positive effect on dividend policy. Based on the results of previous studies, then the hypothesis formulated as follows:

\section{H8: Activity effect on dividend policy positively related to large Indonesian firms (+).}

\subsubsection{Effect of Dividend Policy on Firm Value}

If a company increases dividend payments, it can be interpreted by investors as a signal of management's expectations about the company's improved performance in the future. The company's performance and business prospects are getting better, so investors will be interested in buying shares. Furthermore, the company's stock returns will increase (Kasmiati and Santosa, 2019; Breuer et al. 2014) supported by signaling theory which says if there is an increase in dividends, often followed by an increase in share prices, conversely a decrease in dividends causes a decrease stock price. Based on the findings by Putu et al. (2014), Hashim and Davidas (2018), Santosa (2020) who examined the effect of dividend policy on firm value, states that dividend policy has a positive and significant effect on firm value. Based on the results of previous studies, then we formulated the hypothesis as follows:

H9: Dividend policy effect on firm value positively related to large Indonesian firms (+).

\subsubsection{Effect of Profitability on Firm Value Mediating Dividend Policy}

Large companies with high profits are supported by proper management in determining the distribution of dividends so that they can affect the value of the company. The distribution of the right dividends can cause a positive signal for the market, causing the company's value to rise (Basheer et al. 2019; Kajola et al. 2015). The results of Kajola et al. (2015), Puspitasari and Santosa (2019), and Kanwal and Hameed (2018) research shows that profitability has a significant positive effect on firm value through dividend policy. Based on the results of previous studies, then the hypothesis can be formulated as follows:

H10: Profitability effect on firm value mediating by dividend policy positively related to large Indonesian firms (+). 


\subsubsection{Effect of Liquidity on Firm Value Mediating Dividend Policy}

Kasmiati and Santosa (2019) state that liquidity has a positive or negative impact on dividend policy depend on capital expenditure, internal funding, and business cycle of the firms. However, generally, that increasing liquidity tends to pay dividends more than before or a positive correlation between liquidity and dividend policy (Brigham and Houston, 2016). Basheer et al. (2019) also support the argument that liquidity had a positive and significant effect on firm value. Hashemijoo et al. (2012) and Kajola et al. (2015) explained that dividend policy tends to has a positive effect on firm value as a good signal to investors and debtholders in the market. Based on the results of previous studies, then the hypothesis can be formulated as follows:

H11: Liquidity has a positive effect on firm value mediating by dividend policy related to large Indonesian firms (+).

\subsubsection{Effect of Leverage on Firm Value Mediating Dividend Policy}

Arowoshegbe and Emeni (2014) and Santosa and Puspitasari (2019) conclude that leverage harms dividend policy or, in other words, the relationship between leverage and dividend policy in the negative correlation. According to and Kajola et al. (2015) and Pertiwi (2016) explained that dividend policy has a positive and significant effect on firm value. According to the previous explanation, the direct and indirect effect may a positive or negative impact on firm value. Based on the results of previous studies, then the hypothesis can be formulated as follows:

H12: Leverage effect on firm value mediating by dividend policy negatively/positively related to large Indonesian firms (+/-).

\subsubsection{Effect of Activities on Firm Value Mediating Dividend Policy}

The ratio of activities that are proxied to total asset turnover has a positive and significant effect on the dividend payout ratio. The efficiency of management triggered the sales and profitability of a positive relationship with dividend policy and firm value (Yegon et al., 2014; Adediran and Alade, 2013). Pertiwi (2016) also found that total asset turnover has a positive and significant effect on firm value. Furthermore, Chidinma (2017) and Basheer et al. (2019) states that dividend policy has a positive and significant effect on firm value. According to the previous explanation, the direct and indirect effect may a positive impact on firm value, mediating dividends policy. Based on the explanations of previous studies, the following hypothesis formulated as follows:

H13: Activity effect on firm value mediating by dividend policy positively related to large Indonesian firms (+/-).

\section{Data and Methodology}

\subsection{Population and Sampling}

The population in this study are companies included in the LQ 45 Index, which are 45 of the largest capitalization and most liquid companies on the Indonesia Stock Exchange. Sampling uses a purposive sampling method based on specific criteria and considerations (Santosa and Hidayat, 2014).

The sampling criteria in this study are as follows:

Table 1. Sample selection process

\begin{tabular}{llc}
\hline No & Large firms criteria & No. of Firms \\
\hline 1 & Large firms member of LQ45 index at IDX & 45 \\
\hline 2 & Large firms member of LQ45 index at IDX (2013-2018) & 27 \\
\hline 3 & Non-financial large firms of LQ45 (2013-2018) & 20 \\
\hline
\end{tabular}

\subsection{Research Variables and Measurement Scale}

Table 2. Description of variables

\begin{tabular}{llll}
\hline Variables & Description relationship & Notation & Signed \\
\hline Dependent: & & \\
\hline Firm value & Total MV+BV liabilities to book value of assets & $\mathrm{FV}$ & \\
\hline Intervening: & & & \\
\hline
\end{tabular}




\begin{tabular}{llcc}
\hline Variables & Description relationship & Notation & Signed \\
\hline Dividend policy & Dividend per share/EPS & DP & + \\
\hline Independent: & & & \\
\hline Profitability & Net income/equity & Pft & + \\
\hline Liquidity & Current assets/current liabilities & Liq & $+/-$ \\
\hline Leverage & Total debt/equity & Lev & - \\
\hline Activity & Revenue/total assets & Act & + \\
\hline
\end{tabular}

\subsection{Data Collecting}

Data collection in this study uses secondary data in which collecting with the following instruments:

a. Documentation study, which is a data collection technique used in this research, is a documentation technique which is a collection of data by looking at, analyzing, and quoting written notes that have the allocation of research and other sources related agencies.

b. Literature study, namely the collection of data obtained from books, scientific works, opinions of experts who have relevance to the problem under study.

\subsection{Data Types and Data Sources}

\section{a. Data type}

Secondary data is a source of research data obtained indirectly or data obtained from literature observations, documents from companies, and others.

\section{b. Data source}

Sources of data from companies included in the LQ45 Index on the Indonesia Stock Exchange in the 2013-2018 period. The annual financial reports were gathered from the Indonesia Stock Exchange, Bloomberg, Yahoo Finance, and company website.

\subsection{Data Analysis}

\subsubsection{Multiple Regression Analysis}

The analysis method uses multiple regression models, with the following equation:

$$
\begin{gathered}
F V_{i t}=\alpha_{0}+\alpha_{1} P f t_{i t}+\alpha_{2} L_{i q_{i t}}+\alpha_{3} L e v_{i t}+\alpha_{4} A c t_{i t}+\varepsilon_{t} \\
D P_{i t}=\beta_{0}+\beta_{1} P f t_{i t}+\beta_{2} L_{i t}+\beta_{3} L e v_{i t}+\beta_{4} A c t_{i t}+\varepsilon_{t} \\
F V_{i t}=\delta_{0}+\delta_{1} P f t_{i t}+\delta_{2} \text { Liq }_{i t}+\delta_{3} L e v_{i t}+\delta_{4} A c t+\delta_{5} D P_{i t}+\varepsilon_{t}
\end{gathered}
$$

where:

FV: Firm value (Tobin's Q); DP: Dividend policy; Pft: Profitability; Liq: Liquidity; Lev: Solvency and Act: Activity (Asset turnover).

\subsubsection{Path Analysis}

To test the effect of intervening variables used, the path analysis method. Path analysis is an extension of multiple linear regression analysis, or path analysis is the use of regression analysis to estimate causal relationships between variables (causal models) that have been predetermined based on theory (Santosa and Hidayat, 2014). Path analysis uses panel data in it. Panel data is combining time-series (time-series) data and cross-sectional (individual) data, in essence, showing having a dimension of space and time. Time series data (time-series) is data that has a time series of more than one year on objects or data collected from time to time. While cross-section data is data that has many objects in the same year or data collected at one time against many objects (Gujarati and Porter, 2011).

\subsubsection{Sobel Test}

The procedure of mediation hypothesis testing does by developed by Sobel (1982) and is known as the Sobel test, which conducted by testing the influence of the indirect effect from X to Y through M. Significant measured by the formula as follows:

$$
Z_{\text {Value }}=a \cdot b \sqrt{\left(b^{2} \cdot S a^{2}+a^{2} \cdot S b^{2}\right)}
$$


Decision making criteria: if $\mid$ Zcomputation $|<|$ Ztable $\mid$, then do not reject Ho or reject Ha. whereas if $\mid$ Zcomputation $|>|$ Ztable $\mid$, then reject Ho or do not reject Ha.

\section{Empirical Results and Discussion}

\subsection{Descriptive Statistics}

Based on descriptive statistical results, the results of the study and discussion on the effect of profitability, liquidity, leverage, and activity on firm value described in the dividend policy as an intervening variable. The intervening variable displayed through the characteristics of the sample in this study, namely: mean (mean), maximum value, minimum value, and standard deviation for each variable. Table 3 shows that the number of observations at large companies that included the LQ45 index listed on the Indonesia Stock Exchange in the 2013-2018 period.

Table 3. Descriptive statistics

\begin{tabular}{lrrrr}
\hline Variables & Minimum & Maximum & Mean & Std. Dev. \\
\hline Profitability & .00 & .33 & .1477 & .07289 \\
\hline Liquidity & .78 & 3.36 & 1.8013 & .55151 \\
\hline Leverage & .37 & 1.16 & .7068 & .19442 \\
\hline Activity & .13 & 1.39 & .7419 & .31830 \\
\hline Dividend policy & .00 & .97 & .5933 & .25215 \\
\hline Firm value &. .19 & .59 & .2516 & .17581 \\
\hline
\end{tabular}

The minimum profitability (ROE) is 0.00 , and the maximum is 0.33 . Besides, the ROE value indicates a mean of 0.1477 with a standard deviation of 0.07289 . This finding shows that the data on ROE has a small distribution because the standard deviation is smaller than the mean value. Thus it can be concluded that the data on the ROE variable is good data distribution.

The minimum liquidity $(\mathrm{CR})$ is 0.78 , and the maximum is 3.36 . Also, the $\mathrm{CR}$ value indicates a mean value of 1.8013 with a standard deviation of 0.55151 . This result shows that the data on the CR variable has a small distribution because the standard deviation is smaller than the mean value. Thus it can be concluded that the data on the CR variable is proper data distribution. The lowest (minimum) leverage/solvency (DER) is 0.37, and the highest (maximum) is 1.16. Besides, the DER value indicates an average value of 0.7068 with a standard deviation of 0.19442 . This result shows that the data on the DER variable has proper distribution because the standard deviation is smaller than the mean value. Thus it can be concluded that the data on the DER variable is proper data distribution.

The lowest (minimum) activity ratio (TATO) is 0.13 , and the highest (maximum) is 1.39 . Besides, the TATO value indicates an average value of 0.7419 , with a standard deviation of 0.31830 . This finding shows that the data on the TATO variable has a small distribution because the standard deviation is smaller than the mean value. Thus it can be concluded that the data on the TATO variable is good data distribution. The lowest (minimum) dividend policy (DPR) value is 0.00 , and the highest (maximum) is 0.97 . Also, the DPR value indicates an average value of 0.5933 , with a standard deviation of 0.25215 . This result shows that the data on the DPR variable has a small distribution because the standard deviation is smaller than the mean value. Thus it can be concluded that the data on the DPR variable is proper data distribution.

The minimum firm value (Tobin's $Q$ ) is -0.19 , and the maximum is 0.59 . Besides that, Tobin's $Q$ value shows the mean value of 0.2516 with a standard deviation value of 0.17581 . This analysis shows that the data on Tobin's $Q$ variable has a small distribution because the standard deviation is smaller than the mean. Thus it can be concluded that the data on Tobin's $\mathrm{Q}$ variables are proper data distribution.

\subsection{Regression Analysis Results}

Hypothesis testing using the Multiple Regression model and Path analysis and Sobel Test. Path Analysis is an extension of multiple linear regression or path analysis is the use of regression analysis to estimate causal relationships between variables that have been predetermined based on theory (Santosa and Hidayat, 2014).

The first hypothesis testing states that profitability has a significant positive effect on firm value. The testing of this hypothesis did through testing the significance of the regression coefficient of profitability variables that are proxy of 
Return on Equity (ROE). The first hypothesis of this study states that profitability has a positive effect on firm value. The magnitude of the regression coefficient is 0.947 , and the significance value is 0.000 . At the significance level of $\alpha=5 \%$, the regression coefficient is significant because of $0,000<0.05$, so it concluded that profitability has a significant positive effect on firm value. Thus the Ha1 test following the hypothesis. The results of this study are in line with research conducted by Lubis et al. (2017), Apriadi et al. (2016), and Rehman (2016), who obtained results that have positive profitability effect on firm value, significantly. The large firms that increase in profit have an excellent reputation for attracting lower cost of debt to expand operations and, thus, increase both share price and firm value.

Table 4. Regression analysis results

\begin{tabular}{lllllll}
\hline Variable & Model 1 & \multicolumn{5}{c}{ Model 2 } \\
\hline & Coeff & Sig & Coeff & Sig & Coeff & Sig \\
\hline $\mathrm{C}$ & 0.268 & 0.018 & .539 & .004 & .124 & .251 \\
\hline Profitability & 0.947 & 0.000 & .750 & .055 & .747 & .001 \\
\hline Liquidity & -0.039 & 0.202 & -.120 & .020 & -.007 & .803 \\
\hline Leverage & -0.343 & 0.000 & -.140 & .324 & -.305 & .000 \\
\hline Activity & 0.211 & 0.000 & .349 & .000 & .118 & .033 \\
\hline Dividend policy & - & - & - & - & .267 & .001 \\
\hline
\end{tabular}

The second hypothesis of this study states that the liquidity effect on firm value, insignificantly. The testing hypothesis results in the significance of the regression coefficient of the liquidity variable, which is proxied by the current ratio (CR). The magnitude of the regression coefficient is -0.039 , and the significance value is 0.202 . At the significance level $\alpha=5 \%$, the variable is insignificant because of $0.202>0.05$, so it concluded that liquidity does not affect firm value. The market does not appreciate the firm which has a high level of liquidity (over-liquid) because they think management failed to use liquidity for increase value of the firm (Van Horne and Wachowics, 2012; Subrahmanyam, 2014). These results indicate that if the Current Ratio increases, it does not affect the Tobins' Q value, although the current ratio also shows the level of security of short-term creditors or the company's ability to cover short-term debts. The results of this study are in line with research conducted by Kasmiati and Santosa (2019), Kanwal and Hameed (2017), Sugiastuti et al., (2018), and Pertiwi (2016) which show that liquidity does not affect the value of the firm.

The third hypothesis of this study states that leverage has a significant negative effect on firm value. The testing of this hypothesis results which testing the significance of the regression coefficient of the leverage variable, which is proxied by the debt to equity ratio (DER). The magnitude of the regression coefficient is -0.343 , and the significance value is 0,000 . At the significance level of $\alpha=5 \%$, the DER is significant because of $0,000<0.05$, so it concluded that leverage has a significant negative effect on firm value. This finding is in line with research conducted by Lubis et al. (2017) and Gill (2012), Imelda and Sheila (2018) and Kasmiati and Santosa (2019) who find that leverage has a significant negative effect on firm value because shareholders thing that increasing of leverage will trigger the probability of deterioration or cash flow problems, even financial distress, besides tax-deductible.

The fourth hypothesis of this study states that the efficiency of assets has a significant positive effect on firm value. The testing of this hypothesis did through testing the significance of the regression coefficient of the activity variable, which is proxied through total assets turnover (TATO). The magnitude of the regression coefficient is 0.211 , and the significance value is 0.000 . At the significance level $\alpha=5 \%$, the regression coefficient is significant because of $0,000<0.05$, so it concluded that activity has a significant positive effect on firm value. This finding is in line with research conducted by Putu et al. (2018), Sugiastuti et al. (2018), who concluded that TATO had a significant positive effect on firm value. The large firms that increase efficiency have an excellent reputation for attracting lower cost of debt to expand business operations and, thus, increase both share price and firm value.

The fifth hypothesis of this study states that profitability (ROE) has a positive effect on dividend policy. The magnitude of the regression coefficient is 0.750 , and a significance value of 0.055 . At the significance level of $\alpha=5 \%$, the coefficient is not significant because of $0.055>0.05$, so it concluded that profitability does not affect dividend policy. So that H5 be rejected. This result is not in line with research conducted by Adediran and Alade (2013), 
Sugiastuti et al. (2018), and Santosa (2019), which stated that profitability has a significant positive effect on dividend policy. The results of this study prove that large companies in Indonesia that obtain profits will not necessarily share their profits in the form of dividends because the management prefers used profits for business expansion and diversification.

The sixth hypothesis of this study states that liquidity has a positive effect on dividend policy. The liquidity variable is proxied by the current ratio (CR). The magnitude of the regression coefficient is -0.120 and a significance value of 0.020 . At the significance level of $\alpha=5 \%$, the liquidity coefficient is significant because $0.020<0.05$, so it concluded that liquidity has a significant negative effect dividend policy. So that $\mathrm{H} 6$ was rejected. This finding is not in line with research conducted by Sandy and Asyik (2013); Putu et al. (2014), who show that liquidity has a significant influence on dividend policy. However, the results of this study support the conclusion from Sugiastuti et al. (2018), and Hashim and Davidas (2018), which the company's liquidity is not for pay cash dividends, but rather is used to pay maturity debts or is used to finance the company's operational costs and business expansion plan. In this case, related to large firms in Indonesia, some of them have set the dividend payout ratio, which not influenced by the changing of liquidity.

The seventh hypothesis of this study states that leverage negatively affects dividend policy. The leverage variable is proxy by the debt to equity ratio (DER). The magnitude of the regression coefficient is -0.140 and a significance value of 0.324 . At the significance level of $\alpha=5 \%$, the coefficient is not significant because $0.324>0.05$, so it concluded that leverage does not affect dividend policy. So that $\mathrm{H} 7$ cannot be accepted. This result is in line with research conducted by Putu et al. (2014) and Kasmiati and Santosa (2019), which says that leverage does not affect dividend policy. Besides, the results of this study found that the company's capital fulfills long-term corporate obligations such as bank loans, bond debt, and others, which are usually preferred first before paying dividends. Because the large companies pay dividends with the target dividend payout depends on the agreement between management and shareholders of each company with some strategic reasons. Whereas if the firms must cover both short-term and long-term debt on the maturity date.

The eighth hypothesis says that activity has a significant positive effect on dividend policy. Activity variables are proxy by the total assets turnover (TATO). The magnitude of the regression coefficient is 0.349 , and the significance value is 0.000 . At the significance level $\alpha=5 \%$, the regression coefficient is significant because of $0.000<0.05$, so it concluded that the activity has a positive and significant effect on firm value. So that Ha8 can be accepted. The results of this study are in line with what is explained by Kolawole et al. (2018) and Kajola et al. (2015) that the efficiency ratio, which is represented by the total asset turnover, has a positive and significant effect on dividend policy. Firms that increase in efficiency attributed to investment growth opportunities; hence, the effect on their cash dividend policy (pay less) (Ofori-Sasu et al. 2017).

The ninth hypothesis says that dividend policy has a significant positive effect on firm value. Dividend policy variables are proxied by the dividend payout ratio (DPR). The magnitude of the regression coefficient is 0.267 , and a significance value of 0.001 . At the significance level $\alpha=5 \%$, the regression coefficient is significant because of $0.001<0.05$, so it concluded that dividend policy has a significant positive effect on firm value. So that $\mathrm{Ha} 9$ can be accepted by its testing. This finding is in line with research conducted by Putu et al. (2014), Hashim and Davidas (2018), Sugiatuti et al. (2018), who examined the effect of dividend policy on firm value stating that dividend policy has a positive and significant effect on firm value. The large firms that increase in dividend policy have a good reputation for attracting lower cost of equity to expand business operations and, thus, increase both share price and firm value.

\subsection{Path Analysis Results}

The results of path analysis about impact profitability, liquidity, leverage, and activity on firm value, directly and indirectly, through intervening variable, which mediating by dividend policy. Figure 1. shows that all variable coefficient. 


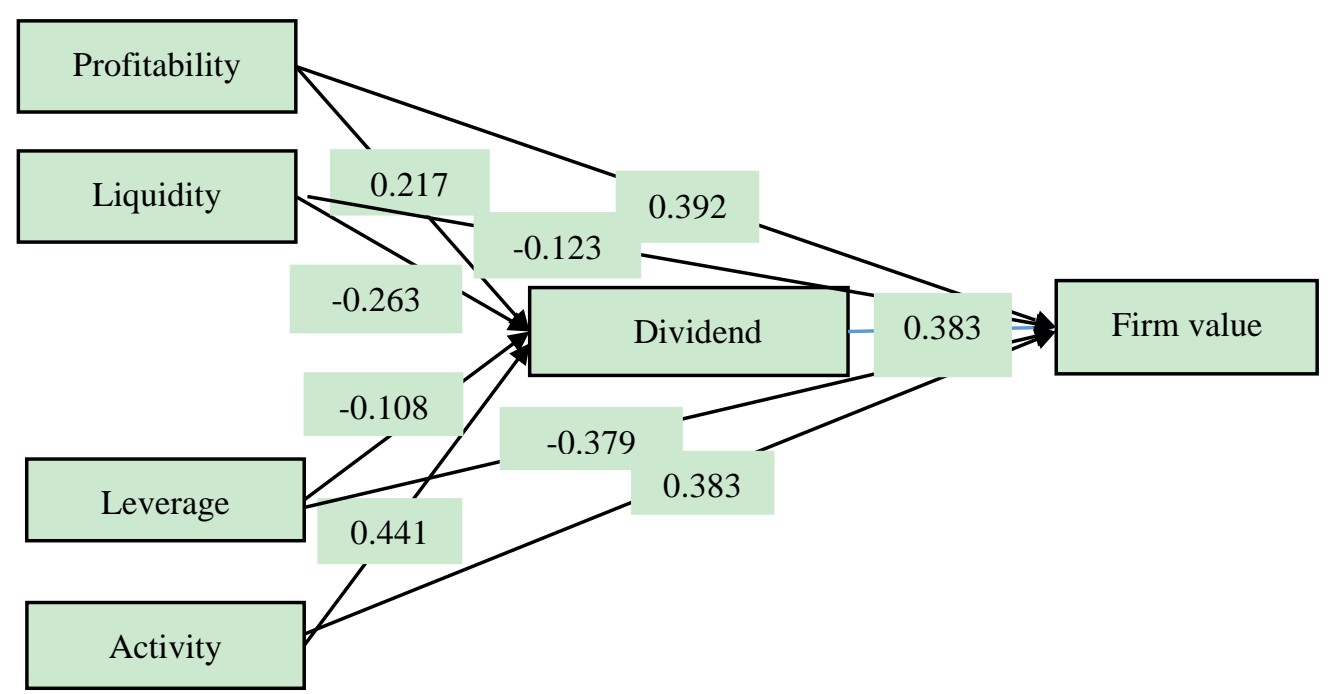

Figure 1. Path analysis diagram results

\subsection{Sobel Test Results}

This analysis shows the results of the analysis of Sobel testing with profitability, liquidity, leverage, and activity variables to get the results of the direct influence on firm value and the indirect effect of mediating dividend policy, in the context of large companies in Indonesia. Table 5 shows an insignificant relationship between profitability and firm value, mediating dividend policy; the same results for liquidity and leverage shows the insignificant correlation between liquidity and leverage with firm value, mediating dividend policy. Unlike previous results, the activity variable shows a significant correlation with firm value mediating dividend policy.

Table 5. Results of Sobel Testing

\begin{tabular}{lcccccl}
\hline Variable & \multicolumn{2}{c}{$\mathrm{X} \rightarrow$ Div. policy } & \multicolumn{2}{c}{ Div. policy $\rightarrow \mathrm{FV}$} & $\mathrm{Z}$ value & \multicolumn{1}{c}{ Results } \\
\hline \multicolumn{1}{c}{$\mathrm{A}$} & $\mathrm{Sa}$ & $\mathrm{B}$ & $\mathrm{Sb}$ & & \\
\hline Profitability & 0,750 & 0,383 & 0,267 & 0,073 & 1.726 & significant \\
\hline Liquidity & $-0,120$ & 0,050 & 0,267 & 0,073 & -2.006 & insignificant \\
\hline Leverage & $-0,140$ & 0,141 & 0,267 & 0,073 & -0.958 & insignificant \\
\hline Activity & 0,349 & 0,086 & 0,267 & 0,073 & 2.716 & significant \\
\hline
\end{tabular}

Where X: independent variables such as profitability, liquidity, leverage and activity ratio; Div. policy: intervening variable; $\mathrm{FV}$ : firm value; $\mathrm{Z}$ value $=\mathrm{Z}$ computation; $\mathrm{A}$ : Unstandardized coefficients $\mathrm{A}$; Sa: standard error $\mathrm{A}$; $\mathrm{B}$ : Unstandardized coefficients B; and Sb: Standard Error B.

The tenth hypothesis testing uses the coefficient of the direct and indirect effect of the profitability (ROE). The results of the path analysis show that the direct and indirect effect of profitability on the value of the firm (Tobin's Q) intervening dividend policy (DPR) is 0.392 and $(0.217 \times 0.383=0.083111)$ while the dividend policy mediated the effect of total ROE on Tobin's Q is $0.392+0.083111=0.475111$. Based on Table 5, the $\mathrm{z}$ computation is 1.726 , and the $\mathrm{z}$ table for the $5 \%$ significance level is 1.645 . The $\mathrm{z}$ computation $>\mathrm{z}$ table so that it concluded that profitability has a significant positive effect on company value with dividend policy as an intervening variable, and H10 was accepted.

According to those results, it concluded that profitability affects firm value with dividend policy as an intervening variable. The findings are in line with research conducted by Al-Shubiri (2012) and Ofori-Sasu et al. (2017), showing that profitability has a significant positive effect on firm value with or without mediating dividend policy. The result alleged because the profitability obtained by the company does not increase payment in dividends but instead adding retained earnings as reinvestment for business expansion growth so that it did not have an impact on the company's 
value in the short term (Kajola et al. 2015; Ahmad and Ali, 2016; Osamwonyi1 and Lola-Ebuek, 2016). Therefore, dividend policy is not able to be an intervening variable between profitability and firm value because of the growth of the business firm more critical than increase dividend payment (Ofori-Sasu et al., 2017).

The eleventh hypothesis testing uses the coefficient of the direct and the indirect effect of the liquidity variable (CR). The results of the path analysis show that the direct and indirect effect of liquidity (CR) on the value of the company (Tobin's Q) mediating dividend policy (DPR) is -0.263 and $(-0.123 \times 0.383=-0.047109)$ while the total effect of CR on Tobin's $\mathrm{Q}$ through the dividend policy is $-0.263-0.047109=-0.310109$. Based on Table 5 , $\mathrm{z}$ computation is -2.006 and $\mathrm{z}$ table for a significant level of $5 \%$ is 1.645 , then $\mathrm{z}$ computation $<\mathrm{z}$ table so that it concluded that liquidity does not affect the value of the firm with dividend policy as a mediating variable and H11. The result was estimated because the company's liquidity was not used to pay dividends but was used to pay a short-term debt that was due, or was used to finance the company's operating expenses, so liquidity did not impact on the firm value mediating dividend policy (Chauhan1 et al. 2019; Farooq, 2016; Al-Shubiri, 2012).

The twelfth hypothesis testing uses the coefficient of direct influence and the indirect effect of the leverage variable. The results of the path analysis show that the direct and indirect leverage (DER) effect on firm value (Tobin's Q) through dividend policy is $-0,379$ and $(-0,108 \times 0.383=-0.041364)$ while the total effect of DER on Tobin's Q through the dividend policy is $(-0.379-0.041364)=-0.420364$. Based on Table 5 , the $\mathrm{z}$ count is -0.958 , and the $\mathrm{z}$ table for the $5 \%$ significance level is 1.645 , then the $\mathrm{z}$ computation $<\mathrm{z}$ table so that it stated that leverage has no effect on company value with dividend policy as an intervening variable and $\mathrm{H} 12$ was rejected. This result is not surprising because although leverage affects the value of the company, leverage does not affect the dividend policy. After all, the company capital considered paying the company's long-term liabilities, which are usually preferred first before paying dividends. So that dividend policy is not working be an intervening variable between leverage and firm value (Arowoshegbe and Emeni, 2014; Chauhan1 et al. 2019; Ahmad and Ali, 2016). The results of the study reporting the number of variables of debt to equity (capital structure), and dividend payout policy has a significant effect on the dependent variable (Tobin's Q).

The thirteenth hypothesis testing uses the coefficient of direct and indirect effects of the activity ratio (TATO). The results of the path analysis show that the direct and indirect effect of activity ratio on the value of the firm (Tobin's Q) was mediating by dividend policy is 0.383 and $(0.441 \times 0.383=0.168903)$ while the total effect of activity on Tobin's $Q$ through the dividend policy is $0.383+0.168903=0.551903$. Based on Table $5, \mathrm{z}$ computation is 2.716 , and the $\mathrm{z}$ table for a significant level of $5 \%$ is 1.645 . Z computation $>\mathrm{z}$ table so that it concluded that activity has a significant positive effect on company value with dividend policy as an intervening variable, and $\mathrm{H} 13$ was accepted. These results are line with previous studies such as Farooq (2016), Al-Shubiri (2012), Priya and Nimalathasan (2013), and Kajola et al. (2015).

\section{Conclusion}

Based on the results of the empirical results above, it concluded that profitability has a significant positive effect on firm value. Liquidity affects the value of the firm negatively because of the increase in liquidity harms profitability but a positive effect on operational risk. These results show that liquidity does a negative effect on firm value, although liquidity also indicates the level of security of short-term creditors or the company's ability to meet its short-term debts. Furthermore, leverage negatively affects the value of the firm caused by over target of debt, which increases financial distress, thereby reducing the value of the firm. Activities have a significant positive effect on company value because investors value, the higher the efficiency of management in managing assets, the higher the firm value will be.

Large firms will not necessarily pay their dividends as a good sign to market; they preferred to choose to financed investment with the retained earnings for business expansion and the company's growth. This explanation is related to the business cycle in which large companies tend to grow well to set a dividend policy that suits their internal capital needs. Furthermore, liquidity does not affect dividend policy because corporate liquidity pays the long-term debt that is maturity or is used to finance the company's capital expenditure, preferably.

Leverage does not affect dividend policy because the company's capital policy intended for long-term investment companies such as capital expenditure, business expansion, and other strategic decisions. However, management must maintain its flexibility in the market by distributing dividends that grow well as a positive signal to its shareholders. That is because the payout of the dividends depends on the dividend policy of each company's characteristics, and of course, based on management and shareholder agreements. Nevertheless, for both short-term and long-term debt must be paid on the due date, so there is an interest between the two. Other findings are that the activity has a positive effect on dividend policy and dividend policy has a positive effect on firm value, significantly. 
Profitability affects the value of the company with dividend policy as an intervening variable because the payment of dividends does not affect the value of the firm. So the dividend policy as an intervening can reduce the effect of profitability on firm value. Then, liquidity has no effect on firm value with dividend policy as an intervening variable. The result was alleged because the company's liquidity was not used to pay dividends but prefer was used to pay the short-term debt that was due, or was used to finance the company's operating expenses, so liquidity did not affect the company's value through dividend policy.

Dividend policy is critical to the firm uses to decide the payout ratio. It will pay shareholders trade-off with the growth of the large firms in Indonesia. For shareholders, dividend policy does have not only implications for them but also different stakeholders, especially government and debtholders. Dividend policy decisions by different large firms are influenced by many different factors, such as business cycles, thus leading to mixed results in both developed and emerging market study. The share price of a company's common stock is a crucial measure of its shareholders' wealth. As previous analysis and explained earlier, the optimal decision of dividend policy is the choice that maximizes the common stock of that company as a firm value, which also results in maximization shareholders' wealth.

\section{Acknowledgments}

Thanks to all the colleagues and reviewers who provided valuable input, critics, and feedback on this article.

\section{References}

Adediran, S. A., \& Alade, S. O. (2013). Dividend policy and corporate performance in Nigeria. American Journal of Social and Management Sciences, 4(2), 71-77.

Ahmad, N., \& Ali, M. (2016). Impact of capital structure on firm's financial performance: Cement industry of Pakistan. European Journal of Business and Management, 8(4), 115-119. https://doi.org/10.14738/abr.46.2367

Ali, S. (2016). Corporate governance and stock liquidity in Australia: A pitch. Accounting and Management Information Systems, 15(3), 624-631. https://doi.org/10.2139/ssrn.2729534

Al-Shubiri, F. (2012). Determinants of changes dividend behavior policy: Evidence from the Amman stock exchange. Far East Journal of Marketing and Management, 4(2), 1-13.

Apriadi, I., Sembel, R., Santosa, P. W., \& Firdaus, M. (2016). Banking fragility in Indonesia: A panel vector autoregression approach. International Journal of Applied Business and Economics Research, 14(14), 1193-1224.

Arowoshegbe, A., \& Emeni, F. (2014). Shareholders' wealth and debt-equity mix of quoted companies in Nigeria. International Journal of Financial Research, 5(1), 107-113. https://doi.org/10.5430/ijfr.v5n1p107

Basheer, M. F., Hafeez, M. H., Ali, R., \& Akhtar, S. (2019). The Paradox of Managerial Dividend Policy in Corporate Malaysia. Review of Economics and Development Studies, 5(1), 197-204. https://doi.org/10.26710/reads.v5i1.394

Breuer, W., Rieger, M., \& Soypak, K. (2014). The behaviorals foundation of corporate dividend policy a cross-country analysis. Journal of Banking and Finance, 42, 247-265. https://doi.org/10.1016/j.jbankfin.2014.02.001

Brigham, E. F., \& Houston, F. J. (2016). Fundamentals of Financial Management (14th ed.). International, Singapore: Cengage Leraning.

Chauhan1, J., Ansari, M. S., Taqi, M., \& Ajmal, M. (2019). Dividend Policy and Its Impact on Performance of Indian Information Technology Companies. International Journal of Finance and Accounting, 8(1), 36-42.

Chidinma, O., Okaro, S., \& Okoye, P. (2013). Shareholder's value and firm's dividend policy: evidence from public companies in Nigeria. Research Journal of Management Sciences, 2(12), 26-28.

Farooq, M. A. (2016). Impact of Financial Leverage on Value Firms. Research Journal of Finance and Accounting, $7(9)$.

Gill, A. (2012). The Impact of Corporate Governance and Financial Leverage on the Value of American Firms. International Research Journal of Finance and Economics.

Hashemijoo, M., Ardekani, A., \& Younesi, N. (2012). The impact of dividend policy on share price volatility in the malaysian stock market. Journal of Business Studies Quarterly, 4(1), 111-129.

Hashim, S. L., \& Davidas, S. M. (2018). The Impact of Dividend Policy on Shareholders' Wealth in Malaysia, Global Business and Management Research: An International Journal, 10(3), 354-361. 
Hull, T. J. (2017). How the timing of dividend reductions can signal value. Journal of Corporate Finance, 30, 114-131. https://doi.org/10.1016/j.jcorpfin.2014.12.011

Imelda, E., \& Sheila, E. (2018). The Influence of Capital Structure, Dividend Policy and Ownership Structure on Firm Value. International Journal of Economic Perspectives, 11(4), 558-565.

Kajola, S. O., Adewumi, A. A., \& Oworu, O. O. (2015). Dividend pay-out policy and firm financial performance: Evidence from Nigerian listed non-financial firms. International Journal of Economics, Commerce and Management, 3(4), 1-12.

Kanwal, M., \& Hameed, S. (2017). The relationship between dividend payout and firm financial performance. Research in Business and Management, 4(1), 5-13. https://doi.org/10.5296/rbm.v4i1.10784

Kasmiati, M., \& Santosa, P. W. (2019). The effect of earning information, cash flow components, and financing decision on stock return: empirical evidence on Indonesia stock exchange. Journal of Economics, Business and Accountancy Ventura, 22(2). https://doi.org/10.14414/jebav.v22i2.1638

Kolawole, E., Sadiq, M. S., \& Lucky, O. (2018). Effect of dividend policy on the performance of listed oil and gas firms in Nigeria. International Journal of Scientific and Research Publications, 8(6). https://doi.org/10.29322/IJSRP.8.6.2018.p7837

Lubis, I. L., Sinaga, B. M., \& Sasongko, H. (2017). Pengaruh Profitabilitas, Struktur Modal, dan Likuiditas terhadap Nilai Perusahaan. Jurnal Aplikasi Bisnis dan Manajemen, 3(3), 458-465. https://doi.org/10.17358/jabm.3.3.458

Nwamaka, \& Ezeabasili. (2017). Effect of Dividend Policies on Firm Value: Evidence from Quoted Firms in Nigeria. International Journal of Management Excellence, 8(2). https://doi.org/10.17722/ijme.v8i2.290

Osamwonyi1, I. O., \& Lola-Ebuek, I. (2016). Does Dividend Policy Affect Firm Earnings? Empirical Evidence from Nigeria, International Journal of Financial Research, 7(5), 77-86. https://doi.org/10.5430/ijfr.v7n5p77

Pertiwi, N. T. (2016). Pengaruh profitabilitas, kepemilikan manajerial, DER dan FCF terhadap nilai perusahaan melalui DPR. Jurnal Ilmu dan Riset Akuntansi, 5(2), 1-25.

Priya, K. A., \& Nimalathasan, B. (2013). Dividend Policy Ratios and Firm Performance: A case study of selected hotels and restaurants in Sri Lanka. Global Journal of Commerce \& Management Perspective, 2(6), 16-22.

Putu, M. N. G., Moeljadi, D., \& Djazuli, A. (2014). Factors affecting firms value of Indonesia public manufacturing firms. International Journal of Business and Management Invention, 3(2), 35-44.

Rehman, O. Ur. (2016). Impact of Capital Structure and Dividend Policy on Firm Value. Journal of Poverty, Investment and Development, 21.

Sandy, A., \& Asyik, N. F. (2013). Pengaruh profitabilitas dan likuiditas terhadap kebijakan dividen kas pada perusahaan otomotif. Jurnal Ilmu dan Riset Akuntansi, 1(1), 58-76.

Santosa, P. W. (2019). Financial Performance, Exchange Rate and Stock Return: Evidence from Manufacturing Sector. Jurnal Manajemen Teknologi, 18(3), 205-217. https://doi.org/10.12695/jmt.2019.18.3.5

Santosa, P. W. (2020). The Moderating Role of Firm Size on Financial Characteristics and Islamic Firm Value at Indonesian Equity Market. Business: Theory and Practice, 21(1), 391-401.

https://doi.org/10.3846/btp.2020.12197

Santosa, P. W., \& Hidayat, A. (2014). Riset Terapan: Teori dan Aplikasi. Jakarta: Globalstat.

Santosa, P. W., Tambunan, M E. and Kumullah, E. R. (2020). The role of moderating audit quality relationship between corporate characteristics and financial distress in the Indonesian mining sector. Investment Management and Financial Innovations, 17(2), 88-100. doi:10.21511/imfi.17(2).2020.08

Santosa, P. W., \& Puspitasari, N. (2019). Corporate Fundamentals, BI Rate and Systematic Risk: Evidence from Indonesia Stock Exchange. Jurnal Manajemen, 23(1), 40-53. https://doi.org/10.24912/jm.v23i1.443

Subramanyam, D. (2014). Financial Statement Analysis (11th ed.). New York: McGraw-Hill.

Sugiastuti, R. H., Dzulkirom, M., \& Rahayu, S. M. (2018). Effect of Profitability, Leverage, Toward Dividend Policy and Firm Value. Russian Journal of Agricultural \& Socio-Economic Sciences, 80(8), 88-96. https://doi.org/10.18551/rjoas.2018-08.12

Van Horne, J., \& Wachowicz, J. M. (2012). Fundamentals of Financial Management. New York: McGraw-Hill.

Yegon, C., Cheruiyot, J., \& Sang, J. (2014). Effects of dividend policy on firm's financial performance: Econometric analysis of listed manufacturing firms in Kenya. Research Journal of Finance and Accounting, 5(12), 136-144. 